\author{
TOMASZ KALISZ \\ ORCID: 0000-0002-9751-3616 \\ Uniwersytet Wrocławski \\ Katedra Prawa Karnego Wykonawczego
}

\title{
KARA POZBAWIENIA WOLNOŚCI NA ZIEMIACH POLSKICH OD XV DO POŁOWY XIX WIEKU
}

\begin{abstract}
Abstrakt: Opracowanie prezentuje powstanie i rozwój kary pozbawienia wolności w Polsce do XIX wieku. Dawne prawo polskie, w zakresie szeroko rozumianych kar na wolności, przewidywało kilka znacznie różniących się między sobą form izolacji. Różnice te były konsekwencją podmiotów, wobec których mogły być stosowane, sposobu wykonywania, konsekwencji zastosowania (środek hańbiący czy też niehańbiący). Różne było także miejsce jej wykonywania — mogły to być lochy, twierdze, zamki, klasztory, więzienia, wynajęte na ten cel karczmy czy też własny dom skazanego. Kara pozbawienia wolności, stając się sankcją, wyraźnie przyśpieszyła zmianę średniowiecznego systemu wykonywania kar opartego na karach cielesnych w stronę nowożytnych systemów karnych opartych na izolacji jako samodzielnej i dominującej sankcji karnej.
\end{abstract}

Słowa kluczowe: kara pozbawienia wolności, historia kary, więzienie, prawo karne

Z prawnie określonym zagrożeniem karą pozbawienia wolności w naszym kraju spotykamy się po raz pierwszy w 1447 roku, w Statutach Kazimierza Jagiellończyka ${ }^{1}$. W praktyce do XVIII wieku karze tej przypisywano raczej drugorzędne znaczenie. Dawne prawo polskie, w zakresie szeroko rozumianych kar na wolności, przewidywało kilka znacznie różniących się między sobą form izolacji. Różnice te były konsekwencją podmiotów, wobec których mogły być stosowane, sposobu wykonywania, konsekwencji zastosowania — środek hańbiący czy też niehańbiący, a przede wszystkim miejsca jej wykonywania (mogły to być lochy, twierdze, zamki, klasztory, więzienia, wynajęte na ten cel karczmy, własny dom

1 Odpowiedni przepis stanowił, że kto by sąd naszedł i gwałt uczynił w swej sprawie, będzie karany winą Statutu i do więzienia (carceribus) na niedziel 12 skazany ma być. Zob. J. Rafacz, Dawne polskie prawo karne, Warszawa 1932, s. 135; J.J. Wąsik, Kara dożywotniego więzienia w Polsce, Warszawa 1963, s. 12; a także S. Lelental, Wykład prawa karnego wykonawczego z elementami polityki kryminalnej, Łódź 1996, s. 25. Usankcjonowały ją konstytucje sejmowe z lat 1493 i 1496. 
skazanego itp.). Do kar tego typu zaliczano karę wieży dolnej, karę wieży górnej, więzienie, dom poprawy, dom pracy, a także mające nieco odmienny charakter kary — klatki, kuny, kłody, gąsiory, biskupa i aresztu domowego².

Kara klatki była środkiem stosowanym głównie w miastach, rzadziej na wsiach. Poza dolegliwością związaną z pozbawieniem wolności, nosiła charakter kary na czci. Specjalna klatka zwyczajowo umieszczana była obok ratusza, tak aby wszyscy mogli ją dobrze widzieć. Umieszczano na niej także tabliczki, na których podawano przyczyny zastosowania rzeczonej sankcji ${ }^{3}$. Sankcja wymierzana była w przedziale od jednej godziny do jednego tygodnia, w praktyce najczęściej stosowano wymiar jednego dnia. Kłoda — był to rozłupany na dwie części pniak mający wycięcia, w które wkładano ręce i nogi, które następnie były zamykane specjalnymi klamrami. Kara ta nie była najczęściej długa, stosowano ją za kradzież czy też nieposłuszeństwo. Kolejna z dawnych kar to tak zwany gąsior - przyrząd służący do zamykania skazanego za szyję w pozycji na czworaka. Stosowano go wobec plebejuszy za nieposłuszeństwo, obrazę, picie w karczmie. Wymiar sankcji sięgał zwyczajowo do trzech dni, przy czym każdego dnia skazany miał być przetrzymywany przez trzy godziny pod strażą, tak aby się nie udusił. Kuną nazywano łańcuch umieszczony przy pręgierzu lub drzwiach kościoła, w którym skazanego zamykano za szyję bądź rękę. Kara ta odgrywała istotną rolę w praktyce miejskiej i wiejskiej, stosowano ją za nieposłuszeństwo, obrazę itp. ${ }^{4}$ Bardzo nietypowa była kara określana nazwą ,biskup” — była to procedura umieszczania skazanego w specjalnie wydrążonym drzewie, które następnie zamykano dwoma drągami - wszystko w ten sposób, aby skazany w takim zamknięciu musiał stać. W dawnym prawie polskim znany był także areszt domowy stosowany w praktyce sądowej jako forma złagodzenia kary pozbawienia wolności. Aresztanta pozostawiano w domu, pod asystą straży żołnierskiej, z zakazem jego opuszczania.

Bardziej zbliżonym do izolacji środkiem była kara wieży (poena turris). Zaczęto ją stosować na szerszą skalę pod koniec XV wieku. Wieża była więzieniem czasowym na okres od jednego tygodnia do roku i sześciu niedziel, a wyjątkowo nawet do czterech lat. Karę tę odbywano albo w tak zwanej wieży dolnej, albo w wieży górnej ${ }^{5}$. Kara wieży dolnej (wieży na dnie) była środkiem o szczególnym stopniu dolegliwości stosowanym za zabójstwo, ale także za niszczenie listów królewskich. Wykonywana była pod ziemią w budowanych w tym celu wieżach (w Koronie wieża dolna miała około dziewięciu metrów głębokości, a na Litwie sięgała aż jedenastu metrów). Skazany przebywał w okropnych

2 J. Rafacz, op. cit., s. 146-150.

3 W. Maisel, Poznańskie prawo karne do końca XVI wieku, Poznań 1963, s. 143-146.

4 T. Maciejewski, Rozdział 1. Rozwój prawa karnego, [w:] System Prawa Karnego, t. 2. Źródta prawa karnego, red. T. Bojarski, Warszawa 2011, s. 100.

${ }^{5}$ L. Rabinowicz, Podstawy nauki o więziennictwie, Warszawa 1933, s. 18-20; a także Z. Kaczmarczyk, B. Leśnodorski, Historia państwa i prawa Polski od połowy XV w. do r. 1795, red. J. Bardach, t. 2, Warszawa 1957, s. 192. 
warunkach sanitarno-higienicznych (wilgoć, zimno, ciemności), często kara ta kończyła się znacznym uszczerbkiem na zdrowiu skazanego. Drugim rodzajem kary wieży była wieża górna stosowana $\mathrm{z}$ reguły za lżejsze przestępstwa. W tym wypadku skazanego zamykano w pomieszczeniach bez specjalnych zabezpieczeń. Jednocześnie skazanemu przysługiwało wiele praw: mógł swobodnie przyjmować gości, samodzielnie przygotowywać sobie pożywienie, utrzymywać służbę.

Obie kary wieży, tak dolnej, jak i górnej, były karami niehańbiącymi, stosowanymi głównie wobec szlachty. W obu przypadkach skazani nie byli zatrudniani do pracy. Wynikało to po części z faktu, iż kara ta dotyczyła szlachty, a także ze sposobu jej wykonywania. Skazani osadzani byli pojedynczo, a w przypadku kary wieży dolnej — w ciemnej wieży. Koszty utrzymania skazanego w wieży ponosił on sam, a nadzór nad wykonywaniem tego środka należał do starosty. Więźnia, w obu przypadkach, nie skuwano kajdanami. Skazany sam zjawiał się do odbycia kary — tak zwane zasięście (zajęcie wieży). Na początku i końcu kary skazany składał odpowiednie zeznanie do ksiąg sądowych. Odbywało się to zawsze w obecności woźnego sądowego i dwóch świadków ze szlachty. Środki te nie miały spełniać żadnych celów wychowawczych, a charakterystyczna forma tak zwanego zasięścia w wieży, mająca znaczenie pewnego manifestu, podkreślała formułę samoukarania.

Ich zupełnym przeciwieństwem była kara więzienia (carceribus) przynosząca ujmę na honorze. Ten środek zdecydowanie najbliższy był wykształconej później nowoczesnej karze pozbawienia wolności. Kara więzienia znana jest w Polsce od końca XVII wieku ${ }^{6}$. Stosowano ją głównie w ramach sądownictwa miejskiego oraz dominalnego, w prawie ziemskim nie odgrywała ona większej roli, a wobec szlachty stosowana była wyjątkowo. Skazanego odstawiano do więzienia siłą, więźniowie pozostawali stale pod strażą, będąc jednocześnie zakuwani w kajdany. Skazanych zmuszano do ciężkich robót zwanych przymusowymi robotami publicznymi (przy wałach, wznoszeniu i naprawianiu zamków i budynków miejskich itp.) $)^{7}$. Carceribus zajmował szczególne miejsce w ramach prawa miejskiego, stając się od schyłku XVII wieku sankcją stosowaną coraz częściej.

$\mathrm{W}$ polskich miastach na karę więzienia połączoną z robotami publicznymi skazywano przestępców rokujących jeszcze nadzieję na poprawę. Roboty publiczne, najczęściej w kajdanach, stanowily rodzaj pokuty za popełniony czyn. W pracy na rzecz społeczności miejskiej widziano także element rekompensaty za wyrządzone zło, ale przede wszystkim był to mechanizm ekonomicznej eksploatacji, taniej siły roboczej. Trudno dziś jednoznacznie stwierdzić, czy wykonywanie prac publicznych

6 J. Bardach, B. Leśnodorski, M. Pietrzak, Historia ustroju i prawa polskiego, Warszawa 1994, s. 270.

7 J. Rafacz, op. cit., s. 140.

${ }^{8}$ W Krakowie już u schyłku XVI wieku zdarzało się, że tamtejsi rajcy miejscy, zamiast skazywać przestępców na śmierć, nakazywali ,ich dacz okowacz [...] aby robili w okowach”. Zob. M. Mikołajczyk, Przestępstwo i kara w prawie miast polski poludniowej XVI-XVIII wieku, Katowice 1998, s. 234. 
miało także za zadanie wychowywanie sprawcy, chociaż wyraźnym znakiem XVI i XVII wieku, szczególnie w społecznościach miejskich, była idea walki z lenistwem, próżniactwem i włóczęgostwem, a co za tym idzie — także z przestępczością związaną z tymi zjawiskami patologii życia społecznego. Nieśmiałym potwierdzeniem tezy o wychowawczym znaczeniu robót publicznych, przynajmniej jako forma pewnej deklaracji, mogą być treści wydawanych pod koniec XVII wieku w Krakowie wyroków, gdzie czasami zaznaczano, że wyznaczając na przykład skazanemu pracę przy uprzątaniu błota z ulic, czyni się to dla poprawy jego życia (,ad correctionis vitam")9. Według szacunków do początku XVII wieku stawki dzienne kajdanników (tak nazywano wyprowadzanych do pracy więźniów) sięgały od jednej trzeciej do połowy uposażenia wolnorynkowego niewykwalifikowanego pracownika ${ }^{10}$.

Wchłonięcie przez karę więzienia środka w postaci robót przymusowych realizowało się w okresie zakładania cuchthauzów — domów poprawy (na wzór domów amsterdamskich ${ }^{11}$ ). Na ziemiach Rzeczypospolitej pierwszy taki dom powstał w 1629 roku w Gdańsku, następne — prawdopodobnie w 1716 roku w Krakowie ${ }^{12}$ i 1736 roku w Warszawie ${ }^{13}$. Powstające w Polsce domy poprawy wzorowane były najprawdopodobniej na wzorcu gdańskim. Większego znaczenia instytucje te nabierają dopiero w połowie XVIII wieku. W ramach tego środka skazani poddawani byli całemu szeregowi ograniczeń oraz obarczani licznymi obowiązkami ${ }^{14}$. Przy karze tej, jak zauważa J. Rafacz ${ }^{15}$, skazany był doprowadzany siłą, odbywał karę pod strażą, ale bez kajdan czy przykucia (te ostatnie stanowiły jedynie kary dyscyplinarne), siedzenie w domu poprawy nie sprowadzało umniejszenia czci, wszystkich odsiadujących obowiązywała praca, która była wyznaczana przez zarząd domu, w zakładach tych utrzymywano majstrów, którzy kształcili więźniów w różnych zawodach, a przygotowani tak skazani po opuszczeniu zakładu mieli

9 Ibidem, s. 235.

10 A. Karpiński, Pauperes, o mieszkańcach Warszawy XVI i XVII w., Warszawa 1983, s. 236; oraz M. Porowski, Społeczne inicjatywy na rzecz więźniów, Warszawa 1991, s. 34.

11 W XVIII wieku było tego typu zakładów w Europie około 60, w Polsce jednak niewiele w Warszawie, Wilnie, Gdańsku, Krakowie, Elblągu i Toruniu. K. Maksymowicz, Z problematyki ksztattowania się instytucji kary opartej na pracy w polskim prawie karnym, [w:] Księga pamiatkowa ku czci Profesora Józefa J. Wąika, red. L. Bogunia, Wrocław 1999, s. 211.

12 Tak M. Mikołajczyk, op. cit., s. 236.

13 Warszawski dom poprawy założony z inicjatywy biskupa Adama Rostkowskiego, mocą uchwały Sejmu z 1736 roku, pod nazwą Dom Corections alias Zuchthaus na „poskromienie złych i swawolnych ludzi”, uzyskał znaczną sławę w Rzeczypospolitej. Był on jednak drugim tego typu zakładem w stolicy. Pierwszym był założony w 1732 roku przez księdza Gabriela Piotra Baudoina dom poprawy. K. Pawlak, Za kratami więzień i drutami obozów. Zarys dziejów więziennictwa w Polsce, Kalisz 1999, s. 12.

${ }^{14}$ Umieszczenie w tych instytucjach odbywało się początkowo na podstawie postanowienia sądu, później przyjęto zasadę, że wystarczy decyzja władzy administracyjnej, a nawet życzenie rodziny. T. Kalisz, Zatrudnienie skazanych odbywajacych karę pozbawienia wolności, Wrocław 2004, s. 18-19.

15 J. Rafacz, op. cit., s. 143-144. 
być traktowani na równi z pozostałymi członkami cechów rzemieślniczych, ważnym elementem poprawy miała być modlitwa i wzmożona nauka religii ${ }^{16}$.

Karą opartą na pozbawieniu wolności były powstające pod koniec istnienia Rzeczypospolitej domy pracy przymusowej. Zakłady te powstawały nie jako instytucje państwowe, ale jako przedsięwzięcia prywatne, którym władza dostarczała jedynie więźniów do pracy, umawiając wcześniej wszystkie związane z tym warunki. Głównym impulsem tworzenia domów pracy przymusowej była, znana już przy genezie domów poprawy, potrzeba zwalczania zjawiska żebractwa i włóczęgostwa oraz związanej z tymi zjawiskami drobnej przestępczości (głównie przeciwko mieniu). Istotna był również charakterystyczna dla tej epoki chęć wykorzystania taniej siły roboczej. Przykładem takiego domu pracy było przedsiębiorstwo Franciszka Rechana.

Właścicielowi, na mocy zawartej — jak podaje J. Rafacz ${ }^{17}$ — w dniu 19 marca 1792 roku z Komisją Policji umowy, powierzono do pracy na siedem lat dwustu więźniów. Na właściciela przedsiębiorstwa przechodziły wszelkie obowiązki związane z zakwaterowaniem, wyżywieniem i ubraniem więźniów, państwo zobowiązywało się jedynie do zapewnienia straży (ochrona przed ucieczką). Skierowani do przedsiębiorstwa kobiety i mężczyźni obowiązani byli pracować dwanaście godzin dziennie z przerwami na posiłek i spanie (z wyjątkiem niedziel i sobót). W umowie szczegółowo regulowano kwestię norm żywieniowych, ubrania oraz wynagrodzenia za pracę. Każdy z więźniów miał otrzymać corocznie w ciągu pierwszych trzech lat swego pobytu, jeżeli był mężczyzną dwie koszule, jedną kamizelkę, jedną parę spodni sukiennych, jedną parę pończoch, jedną szlafmycę i parę butów. W przypadku kobiet dawano każdej po dwie koszule, jednym kaftaniku, jednej spódnicy, jednej parze pończoch, jednym czepku wełnianym i jednej parze trzewików. Ponadto każdy z więźniów miał prawo do koca, siennika i poduszki. Nikt ze skazanych nie otrzymywał w ciągu trzech pierwszych lat wynagrodzenia. Przysługiwało ono dopiero po upływie trzech lat i było wypłacane w ciągu czterech kolejnych lat pobytu. Wynagrodzenie wynosiło 32 złote rocznie na mężczyznę, ponadto zaś liczba sztuk ubrania powiększała się o dwie nowe koszule i parę trzewików tak, iż należały się cztery koszule i dwie pary trzewików. Wszyscy skazani po zwolnieniu mieli mieć stosowne kwalifikacje jako robotnicy. W umowie zwracano także uwagę, aby Rechan założył w domu pracy kaplicę. Więźniom nie pozwalano na przepustki, poza wizytami urzędowymi. Po upływie siedmiu lat skazanego należało wypuścić, chyba że sam wyrażał chęć pozostania — wtedy należało się umówić z nim co do wysokości wynagrodzenia za pracę.

$\mathrm{Na}$ tle opisanego stanu zupełnym wyjątkiem były powstałe w drugiej połowie XVIII wieku dwa bardziej nowoczesne zakłady karne — więzienie marszałkowskie

16 M. Czerwiec, Więzienioznawstwo. Zarys rozwoju więziennictwa, Warszawa 1958, s. 23-24.

17 J. Rafacz, op. cit., s. 145-146. 
w Warszawie (1767 rok) oraz więzienie w Kamieńcu Podolskim $\left(1782\right.$ rok) ${ }^{18}$. Więzienie marszałkowskie w Warszawie uznaje się za historycznie pierwsze polskie więzienie. Powstało ono z inicjatywy marszałka wielkiego koronnego Stanisława Lubomirskiego ${ }^{19}$. Był to zakład doskonale zorganizowany, przeznaczony dla 65 skazanych, administrowany na wzór wojskowy na podstawie wydanej w roku 1767 „Ordynacji więziennej” (uważanej za pierwszy swoisty regulamin więzienny). Ordynacja wprowadzała wiele zmian zarówno w trybie odbywania kary, jak i w organizacji wewnętrznej zakładu. Innowacje te zmierzały w kierunku zapewnienia skazanym odpowiednich warunków higienicznych i sanitarnych (leczenie, utrzymywanie czystości w pomieszczeniach, bielizna oraz odzież na zmianę, własny materac itp.), zapewnienia opieki religijnej, zaprowadzenia robót więziennych oraz wprowadzenia systemu segregacji skazanych. Pozwalano na odwiedziny oraz zezwalano na prowadzenie korespondencji, istniała możliwość skorzystania z przepustek w okresie świątecznym, a przy ostatecznym zwolnieniu dawano odzież więzienną skazanym nieposiadającym własnej. Skazanym dawano również zasiłek pieniężny na drogę w wysokości dwóch złotych polskich ${ }^{20}$. Znamiennym rozwiązaniem ordynacji było przyznanie skazanym prawa do wnoszenia zażaleń do samego marszałka.

Skazani w więzieniu marszałkowskim podlegali obowiązkowi pracy w obrębie zakładu lub w ramach systemu wynajmu poza zakładem. $\mathrm{Z}$ obowiązku pracy zwolnieni byli jedynie skazani za długi ${ }^{21}$. Praca organizowana była na podstawie umów zawieranych przez administrację zakładu z podmiotami prywatnymi względnie z urzędami państwowymi. „Zamówienia pracy” dokonywano u intendenta więzienia (był to mianowany przez marszałka bezpośredni zarządca zakładu), który zgodnie z zaleceniami ordynacji miał, przy uwzględnieniu kolejności zgłoszeń, przydzielać skazanych do pracy ${ }^{22}$. Gdy do wykonania umówionej pracy potrzebne były narzędzia, ich zakupu dokonywała sama jurysdykcja marszałkowska z własnych środków. Postanowienia ordynacji nakazywały zwalnianie z obowiązku pracy chorych skazanych. Obowiązki skazanych dopasowane były

18 Więzienie w Kamieńcu Podolskim powstało w 1782 roku. Karę w twierdzy kamienieckiej odbywali głównie skazani na kary długoterminowe i dożywotnie z całego kraju (około 200 skazanych). Skazani utrzymywani byli przez państwo, które w zamian żądało pracy przy naprawianiu twierdzy. Więzienie to cieszyło się złą sławą. Warunki bytowe i sanitarne były bardzo złe, obowiązujący system wspólnoty sprzyjał demoralizacji, zwłaszcza że nie obowiązywał nakaz milczenia i nie było żadnego wewnętrznego dozoru.

19 Marszałek wielki koronny Stanisław Lubomirski objął swój urząd w 1766 roku, urzędowanie rozpoczął od istotnej reformy kary wieży. Za zgodą króla nakazano w wieży dolnej umieścić okna, założyć posadzkę i zainstalować piec oraz — obok celi — zbudować ubikację dla skazanych. Najważniejszym jednak osiągnięciem marszałka Lubomirskiego było urządzenie, własnym kosztem, nowego więzienia w budynku starej prochowni (kordygardy) przy ulicy Mostowej w Warszawie, uznawanego za pierwsze polskie więzienie. Szerzej zob. J. Rafacz, Więzienie marszałkowskie w latach 1767-1795, Lwów 1932, s. 9-14; M. Czerwiec, op. cit., s. 24-25; J.J. Wąsik, op. cit., s. 33-34.

20 M. Czerwiec, op. cit., s. 25.

${ }^{21}$ K. Pawlak, op. cit., s. 16.

22 J. Rafacz, Więzienie marszałkowskie..., s. 45. 
do możliwości fizycznych tak, aby nadmiernie ciężką pracą ich nie eksploatować. Wysyłani do pracy skazani pozostawali pod stałym nadzorem podoficera i żołnierzy z chorągwi marszałkowskiej. Roboty więzienne organizowane były w taki sposób, aby można było je wykonywać w skupieniu i pod stałym nadzorem. Strażnicy dbali o wydajność i jakość pracy. Komendant straży miał prawo upomnieć skazanego niesumiennie wykonującego powierzone mu zadanie, $\mathrm{w}$ razie gdyby to nie pomogło - mógł uderzyć więźnia kijem w celu przymuszenia go do pracy (z czasem liczbę tych uderzeń ograniczono do trzech razów). Dalszy opór skazanego powodował natychmiastowe odprowadzenie go do więzienia, gdzie następowało dalsze ukaranie. Jako kary za odmowę lub niewłaściwe wykonywanie przydzielonej pracy stosowano czasowe zamknięcie o chlebie i wodzie, a w dalszej kolejności - karę chłosty ${ }^{23}$. Straż żołnierska miała ponadto za zadanie uniemożliwienie kontaktowania się podczas pracy między więźniami a osobami cywilnymi. Kontakt taki dopuszczalny był wyjątkowo i to wyłącznie w obecności komendanta straży. Utrzymywanie skazanych wykonujących pracę było zadaniem urzędu marszałkowskiego. Całość kwot wypracowywanych przez skazanych przejmowana była przez administrację zakładu ${ }^{24}$.

Do końca XVIII wieku organizacja więzień w Polsce była katastrofalna. Praktyczne nie było państwowego sytemu wykonywania kary pozbawienia wolności. Ówczesne prawo dość często pozostawiało powodowi lub oskarżycielowi inicjatywę zarówno w zakresie wszczęcia postępowania karnego, jak i wykonania zapadłego orzeczenia ${ }^{25}$, przenosząc tym samym na powoda lub oskarżyciela wszelkie koszty wykonania wyroku. Kara pozbawienia wolności w tym okresie traktowana była jako sankcja zarówno cywilno-prawna (incarceratio civilis), jak i kryminalna (incarceratio criminalis) ${ }^{26}$. Państwo najczęściej nie było zainteresowane utrzymywaniem więzień, zrzucając ten kosztowny obowiązek na miasta, które z kolei, chcąc obniżyć koszty funkcjonowania instytucji penitencjarnych, oddawały je w dzierżawę.

Pierwszymi próbami przełamania całkowitej inercji struktur państwowych w zakresie organizacji systemu wykonywania kary pozbawienia wolności były reformy stanisławowskie. Powołana w 1775 roku Rada Nieustająca była pierw-

23 Ibidem, s. 47.

24 Więzienie marszałkowskie wyposażone było w specjalny fundusz przeznaczony na jego utrzymanie. Wśród składników tego funduszu wymienić należy: dochód z pracy skazanych, sumy wotowane (przydzielane) przez sejm, stanowiące część budżetu marszałkowskiego przeznaczanego na porządek w miejscu pobytu króla, kredyty publiczne przyznawane w szczególnych przypadkach, jałmużna, część dochodu, jaki uzyskiwała Warszawa z tytułu sprzedaży specjalnych biletów upoważniających Żydów do przebywania w stolicy, oraz dochód ze sprzedaży znalezionych przy złodziejach przedmiotów, po które nie zgłosili się ich prawowici właściciele.

25 M. Porowski, op. cit., s. 24.

${ }^{26} \mathrm{Na}$ temat ewolucji zakresu penalizacji i zasad organizacji procesu wykonywania orzeczeń zob. S. Borowski, Ściganie przestęstw z urzędu w średniowiecznym prawie polskim, Warszawa 1933; oraz R. Taubenschlag, Prawo karne polskiego średniowiecza, Lwów 1934. 
szą próbą centralnego oddziaływania na więziennictwo. Kierowanie skazanych na długoterminowe kary pozbawienia wolności do więzienia w Kamieńcu Podolskim, zalecenie sądom ograniczenia wymierzania kary śmierci, wskazywanie na wychowawczy cel kary, przyznanie dotacji na utrzymywanie skazanych (a następnie na remonty więzień) to przykłady podjętych działań. W 1791 roku powołano Komisję Policji, której powierzono nadzór nad zakładami karnymi oraz nad wykonywaniem kary pozbawienia wolności. Wszystkie te starania dalekie były od upowszechnienia, a ostateczny upadek państwa po trzecim rozbiorze definitywnie przekreślił możliwość dalszych prac w kierunku stworzenia systemu penitencjarnego ${ }^{27}$.

Mimo upadku z końcem XVIII wieku państwa polskiego pod wpływem oświecenia, w poglądach dotyczących organizacji więziennictwa oraz w zakresie zasad wykonywania kary pozbawienia wolności zaszły wyraźne zmiany. Zauważalnym głosem epoki było upatrywanie w karze pozbawienia wolności środka o charakterze poprawczym, a nie jedynie instrumentu odpłaty za popełniony czyn. Postulaty polskiego oświecenia w zakresie reformy systemu penitencjarnego najpełniej wyraził Józef Szymanowski, prawnik, literat i działacz polityczny ${ }^{28}$. Stanowisko Szymanowskiego co do kary więzienia zmierzało w kierunku podkreślenia znaczenia funkcji poprawczej i wychowawczej kary. Zakłady karne winny być oddzielone od aresztów śledczych, a skazani poddani właściwej klasyfikacji. Postulował, aby rodzaj zakładu karnego, gdzie skazany odbywać miał orzeczoną karę, uzależniony był od rodzaju przestępstwa, płci oraz sił fizycznych. Należało wprowadzić podział zakładów karnych na takie, gdzie obowiązuje przymusowa praca, i takie, gdzie kara polegać miała wyłącznie na samym pozbawieniu wolności ${ }^{29}$.

Upadek państwa polskiego nie zniweczył dążeń reformatorskich w dziedzinie więziennictwa i prawa karnego. Mimo narzucenia przez państwa zaborcze swoich rozwiązań w dalszym ciągu można było mówić o rozwoju polskiej myśli penitencjarnej. Potwierdzeniem tej tezy był powstały w latach 1809-1810, w okresie funkcjonowania namiastkowej formy polskiej państwowości, jaką było Księstwo Warszawskie, projekt ordynacji więziennej zatytułowany „Urządzenie więzień krajowych"30. Ten obszerny, liczący 331 paragrafów dokument — jak zauważa J. Śliwowski ${ }^{31}$ - był surogatem ustawy o wykonywaniu kary pozbawienia wolności i regulaminu więziennego. Postulowany model zmierzał do wprowadzenia

27 J. Migdał, J. Raglewski, Kara pozbawienia wolności. Zarys dziejów polskiej doktryny, prawa i polityki penitencjarnej, Gdańsk 2005, s. 143.

28 Józef Szymanowski (1748-1801), wybitny polski prawnik, współtwórca projektu „Kodeksu Stanisława Augusta", kierownik resortu sprawiedliwości podczas insurekcji kościuszkowskiej. Jego rozprawa zatytułowana Myśli do prospektu prawa kryminalnego była podsumowaniem podjętej pod koniec istnienia Rzeczpospolitej Obojga Narodów reformy instytucji karnych.

29 M. Czerwiec, op. cit., s. 50; J. Śliwowski, op. cit., s. 53.

30 Dokument ten został odnaleziony w Archiwum akt dawnych w Warszawie przez J. Śliwowskiego, Akta Rady Stanu Księstwa Warszawskiego; Więzienia i Arsztanci, Sek. II Nr 12A, Nr rd. 121. Pełen tekst tego dokumentu został opublikowany w „Przeglądzie Więziennictwa” 1959, nr 2.

31 J. Śliwowski, op. cit., s. 55. 
wspólnego odbywania kary z elementami progresji. Więzienia miały trafić pod bezpośredni zarząd państwa i stać się strukturą opartą na zasadzie finansowej samowystarczalności (obligatoryjne zatrudnianie wszystkich skazanych). Projekt ordynacji, w związku z upadkiem Księstwa Warszawskiego, nie doczekał się jednak praktycznej realizacji. Okres napoleoński, mimo podejmowanych prób reformy polskiego systemu karnego oraz stworzenia systemu penitencjarnego, zakończył się całkowitym fiaskiem. Pierwszy polski kodeks karny, regulujący także podstawowe zasady wykonywania kary pozbawienia wolności, ostatecznie został opracowany dopiero w 1818 roku w ramach zależnego od Rosji Królestwa Polskiego.

„Gorączka penitencjarna”, która ogarnęła Zachodnią Europę i Stany Zjednoczone w pierwszej połowie XIX wieku, wywoływała na ziemiach polskich zauważalne ożywienie. Coraz śmielsze koncepcje reformatorskie wzmocnione zostały atmosferą wielkiej nadziei na niepodległość (względnie trwałej autonomii), jaką były najpierw Księstwo Warszawskie, a następnie Królestwo Polskie (Królestwo Kongresowe). Polska myśl penitencjarna pierwszej połowy XIX wieku była bardzo ciekawa, w wielu wypadkach znacznie wyprzedzając osiągnięcia europejskie. Warto wymienić nazwiska Juliana Ursyna Niemcewicza, Ksawerego Potockiego, Andrzeja Zamoyskiego, Józefa Pawlikowskiego, Fryderyka Skarbka, Mirosława Nakawskiego, Aleksandra Kożuchowskiego i Józefa Hallera. Szczególną postacią w wymienionym gronie był Julian Ursyn Niemcewicz (1757-1841), wybitny pisarz i poeta, a ponadto działacz polityczny, żywo zainteresowany problematyką więziennictwa ${ }^{32}$. Niemcewicz w swoich pracach zaprezentował nowatorski system poglądów dotyczących kary pozbawienia wolności i jej wykonywania. Postulował skoncentrowanie się na poprawczych i wychowawczych aspektach wykonywania kary pozbawienia wolności. Podkreślał znaczenie właściwie dobranego i dobrze przygotowanego personelu więziennego jako podstawy skutecznie działającego systemu penitencjarnego. Należał do orędowników instytucji warunkowego przedterminowego zwolnienia z reszty kary pozbawienia wolności (przyjmującego prawną formę aktu łaski monarchy). Za ważny element systemu penitencjarnego uważał klasyfikację skazanych ${ }^{33}$. Niemcewicz był zwolennikiem obowiązkowej pracy dla skazanych, ale wyłącznie w obrębie zakładów karnych. Zdecydowanie sprzeciwiał się wynajmowaniu skazanych zewnętrznym przedsiębiorstwom oraz robotom publicznym uznając, iż te są instrumentem hańbiącym.

32 Swoje poglądy dotyczące wykonywania kary pozbawienia wolności przedstawił w dwóch rozprawach - w złożonym w 1807 roku na ręce ówczesnych władz Księstwa Warszawskiego Memoire sur le nouveau systéme des prisons étable dans les Etats-Unis d'Amerique oraz w wydanej w 1818 roku publikacji $O$ Więzieniach Publicznych, czyli Domach Pokuty rzecz krótka.

33 S. Walczak, Poglady J. U. Niemcewicza na prawo karne i wykonywanie kary, ,Przegląd Penitencjarny" 1963, nr 1, s. 9-24; oraz idem, Narodziny i rozwój koncepcji wykonywania kary pozbawienia wolności, [w:] Księga jubileuszowa więziennictwa polskiego 1918-1988, red. A. Marek, Warszawa 1990, s. 39-40. 
Dla najbardziej występnych skazanych postulował urządzić specjalne więzienie w Kunowie koło Radomia, gdzie powinni pracować w kamieniołomach ${ }^{34}$.

Ważnym impulsem $\mathrm{w}$ reformie systemu więziennego na ziemiach polskich było uchwalenie w 1818 roku Kodeksu karzącego obowiązującego na terenie Królestwa Polskiego ${ }^{35}$. Regulacja ta wpisywała się w nurt przeprowadzanych w całej Europie zasadniczych reform $\mathrm{w}$ zakresie prawa karnego oraz organizacji więziennictwa $^{36}$. Początek XIX wieku oznaczał rezygnację z całego katalogu kar hańbiących oraz okaleczających. Na karę śmierci zaczęto patrzeć jak na marnotrawstwo siły roboczej. W miejsce przeżywających się dawnych form represji karnej, stopniowo znikających z regulacji karnych, wchodziła kara pozbawienia wolności. O tak zdecydowanej reorientacji systemów karnych zadecydowały dwie zasadnicze zalety kary pozbawienia wolności - po pierwsze, nie była ona instrumentem eliminującym czy też umniejszającym zasoby siły roboczej, jaką stawali się skazani. Przeciwnie - kara pozbawienia wolności stwarzała doskonałą możliwość pełnego wykorzystania sporej siły roboczej. Po drugie, dawała spore możliwości wychowawczego oddziaływania na skazanego, wyuczenia zawodu i przyzwyczajenia do systematycznej pracy. Po odcierpieniu kary powracający do społeczeństwa skazany powinien być uczciwym obywatelem żyjącym z pracy własnych rąk.

Kodeks karzący uchwalony w 1818 roku dzielił kary na główne — odpowiadające zbrodnią, poprawcze - orzekane za występki i policyjne - orzekane za przewinienia policyjne (art. 4). Do kar głównych kodeks zaliczał: karę śmierci, karę więzienia warownego orzekaną dożywotnio lub na czas od 10 do 20 lat, więzienie ciężkie od 3 do 10 lat. Wśród kar poprawczych wymieniał: dom poprawy od 8 dni do 3 lat, areszt publiczny od 8 dni do 3 lat, grzywnę (do 2000 złotych) oraz karę cielesną w postaci razów w liczbie od 16 do 120 . Za kary policyjne uznawał: grzywnę do 40

${ }^{34}$ K. Pawlak, op. cit., s. 25.

35 Uchwalony w 1818 roku Kodeks karzący Królestwa Polskiego był aktem prawnym wzorowanym na austriackim kodeksie z 1803 roku. Zastąpił on obowiązujące na ziemiach Królestwa pruskiego i austriackiego ustawodawstwo karne.

36 Ostatnie lata XVIII wieku i pierwsza połowa XIX wieku stanowiły w Europie okres ożywionej działalności kodyfikacyjnej. Wśród powstałych w tym okresie kodyfikacji karnych wymienić należy: kodeks karny francuski z 1794 roku; pruski Landrecht z 1794 roku (tytuł XX, część druga) utrzymujący przeżywające się instytucje feudalne; austriacką Theresianę z 1768 roku oraz reformującą ją Josephinę z 1787 roku i będący podsumowaniem tych prac kodeks austriacki z 1803 roku; następnie wydany w 1810 roku nowy francuski kodeks karny, który stał się impulsem dla całego szeregu kodyfikacji w pierwszej połowie XIX wieku; w 1813 roku powstał kodeks karny bawarski (autorstwa A. Feuerbacha), w 1818 roku — Kodeks karzący Królestwa Polskiego, w 1819 roku — kodeks neapolitański, w 1820 roku — kodeks parmeński, w 1822 roku — kodeks hiszpański, w 1832 roku — kodeks państwa kościelnego, w 1834 roku — kodeks grecki, w 1837 roku — kodeks wirtemberski, w 1839 roku — kodeks piemoncki, w 1840 roku — kodeks hanowerski, w 1845 roku — kodeks rosyjski, który trzy lata później z kosmetycznymi zmianami został wprowadzony w Królestwie Polskim. K. Sójka-Zielińska, Historia prawa, Warszawa 1997, s. 295-311. 
złotych, areszt policyjny lub domowy do 8 dni, chłostę do 16 razów ${ }^{37}$. Wprowadzenie w życie Kodeksu karzącego dało wyraźny impuls reformie systemu penitencjarnego. Dodatkowym katalizatorem zmian w systemie więziennym była negatywna ocena urządzeń więziennych będąca wynikiem wizytacji więzień warszawskich przez cara Aleksandra I w roku 1818. Reakcją na tę ocenę było opracowanie przez specjalną Deputację kierowaną przez Ksawerego Potockiego „Projektu ogólnego i szczególnego polepszenia stanu i administracji więzień w Królestwie Polskiem”. W tym samym roku Ksawery Potocki opublikował „Uwagi do Projektu” będące niejako uzasadnieniem i prezentacją motywów przygotowanego projektu reformy systemu więziennego ${ }^{38}$. Dokument zawierający 73 artykuły oraz uwagi Potockiego zawarte w uzasadnieniu podkreślają duże znaczenie sprawnej organizacji systemu więziennego dla prawidłowego wykonywania kary. Podkreślenia wymaga spora troska o zdrowie fizyczne skazanych, ich poziom moralny, wypływająca z postanowień projektu. Cel poprawczy kary był jej głównym zadaniem, odwet stanowić miał element drugorzędny. Najważniejszym środkiem prowadzącym do odnowy moralnej skazanych, według Potockiego i „Projektu”, miało być wpojenie skazanym nawyku pracy $^{39}$. Omawiany projekt, mimo niezwykle przychylnego przyjęcia przez środowiska penitencjarne, nie został zaakceptowany przez władze rosyjskie, głównie z powodu zarzutów o zbytni liberalizm. W zamian przyjęto instrukcję więzienną opracowaną w 1823 roku, która była wyraźnym krokiem wstecz ${ }^{40}$.

Na przełomie lat dwudziestych i trzydziestych XIX wieku rozpoczyna się, niezmiernie owocna dla rozwoju więziennictwa, działalność Fryderyka Skarbka ${ }^{41}$. Jego praktyczna działalność w obrębie więziennictwa rozpoczyna się w 1828 roku,

37 J. Śliwowski, Kodeks Karzacy Królestwa Polskiego (1818 r.). Historia jego powstania i próba krytycznej analizy, Warszawa 1958; M. Senkowska, Kara więzienia w Królestwie Polskim w pierwszej połowie XIX wieku, Wrocław-Warszawa-Kraków 1961, s. 74; E. Kaczyńska, Człowiek przed sądem. Społeczne aspekty przestępczości w Królestwie Polskim 1815-1914, Warszawa 1982, s. 148; eadem, Ludzie ukarani. Więzienia i system kar w Królestwie Polskim 1815-1914, Warszawa 1989, s. 345.

38 Pełen tekst „Uwag do Projektu” został opublikowany w Księdze jubileuszowej więziennictwa polskiego 1918-1928, red. Z. Bugajski, Warszawa 1929, s. 22-44.

39 „do moralnej poprawy istotnym środkiem jest [...] ciągłe więźni zatrudnienie i praca. Te jeżeli siłą i zdrowiu więźni odpowiadaią, ile się przyczyniaią do wzmocnienia ich fizycznego życia, tyle mają wpływu na moralną ich poprawę, bo gnuśność podnieca namiętności, odstręcza, i odzwyczaia ludzi od pracy, która w każdym stanie do uczciwego życia jest potrzebna, rodzi na koniec niesmak i nie ukontentowanie z samego siebie, i niszczy wszelkie do poprawy moralney bodźce". Cyt: K. Potocki, Uwagi do Projektu ogólnego i szczególnego ulepszenia stanu i administracji więzień publicznych w Królestwie Polskiem, [w:] Księga jubileuszowa więziennictwa polskiego..., s. 32.

40 W. Zarzycki, Więziennictwo w czasach Królestwa Polskiego (1818-1840), „Problemy Praworządności" 1983, nr 2, s. 53 n.

${ }^{41}$ Obok intensywnej działalności F. Skarbka duży wkład do dorobku polskiej teorii penitencjarnej w okresie Królestw Polskiego wnieśli Aleksander Kożuchowski, Józef Haller oraz Andrzej Zamoyski. Aleksander Kożuchowski, komisarz wydziału wojskowego i policyjnego w województwie mazowieckim, wydał w 1825 roku interesującą pracę pod tytułem $O$ więzieniach. Z 1825 roku pochodzi także praca Józefa Hallera zatytułowana Myśli o publicznych domach pracy i ich urządze- 
kiedy to jako oficjalny delegat rządu Królestwa zwiedza zakłady karne w Europie, a po powrocie dokonuje inspekcji więzień krajowych. W 1829 roku Skarbek nominowany zostaje na referendarza Rady Stanu Królestwa Polskiego i rozpoczyna gruntowną reformę systemu penitencjarnego. Do jego znaczących osiągnięć jego zaliczyć należy budowę więzień w Sieradzu, Siedlcach, Kaliszu i Płocku. Szczególnym osiągnięciem w jego penitencjarnej działalności było wybudowanie tak zwanego „domu głównego badań” w Warszawie (odpowiednika dzisiejszego aresztu śledczego), który uchodził za wzór w całej Europie. Podczas swej długoletniej działalności zgłaszał wiele postępowych postulatów, wśród których wskazać należy na potrzebę tworzenia więzień ośrodków — rolnych, ułożenia kodeksu (regulaminu) więziennego, zaprowadzenia nadzoru sądowego nad przebiegiem wykonywania kary pozbawienia wolności. Skarbkowi udało się ponadto zaprowadzić w więzieniach porządek i czystość oraz zlikwidować jaskrawe nadużycia. Zadbał także o poprawę warunków bytowych (żywność i ubrania) oraz zwracał uwagę na konsekwentne rozdzielanie poszczególnych kategorii skazanych ${ }^{42}$.

Ciekawym dokumentem epoki było postanowienie Rady Administracyjnej z 19 lipca/10 sierpnia 1832 roku ,nakazujące zaprowadzenie po więzieniach fabryk i warsztatów z wskazaniem, jacy z więźniów w nich pracować mają" ${ }^{33}$. Akt ten przewidywał założenie we wszystkich więzieniach karnych, poprawczych i ciężkich - o ile pozwalały na to miejscowe warunki - fabryk i warsztatów, w których skazani mogliby znaleźć zatrudnienie. Głównym profilem produkcyjnym tych jednostek miały być przedmioty przeznaczone na potrzeby zakładów dobroczynnych i jednostek penitencjarnych. Postanowienie określało, że więźniowie śledczy nie mogli być zmuszani do pracy. Ich użycie do pracy w warsztatach więziennych wymagało, oprócz bezpośredniej zgody skazanych, stosownego orzeczenia sądu (zezwalającego na taką pracę - art. 3). Osadzeni w pojedynczych celach więźniowie śledczy mogli otrzymywać tylko taką pracę, którą byliby w stanie wykonywać w celi ${ }^{44}$. Więźniowie niepoprawni mieli pracować w kompaniach poprawczych aresztanckich przy ciężkich i najcięższych robotach publicznych ${ }^{45}$. Skazani po raz pierwszy na mniej niż 10 lat więzienia cięż-

niach wedlug dzieła Jana Lotza. A. Osoba, Z dziejów polskiej dziewiętnastowiecznej myśli penitencjarnej, „Przegląd Więziennictwa Polskiego” 2001, nr 32-33, s. 110.

42 M. Czerwiec, op. cit., s. 63-82; J. Śliwowski, op. cit., s. 58-59; A. Osoba, op. cit., s. 112-113.

43 ZPA III 295 i n. (Zbiór Przepisów Administracyjnych Królestwa Polskiego, Wydział Spraw Wewnętrznych, cz. VI: O aresztach i więzieniach).

44 M. Senkowska, op. cit., s. 135.

45 Szczególną formą kary związaną z pracą więźniów były tak zwane roty aresztanckie, czasem zwane kompaniami poprawczymi. Ta swoiście rosyjska instytucja, sprzecznie i w zawiły sposób regulowana w prawodawstwie rosyjskim, wprowadzona została w Królestwie Polskim w 1819 roku, choć formalnie w prawodawstwie obowiązującym na ziemiach Królestwa ujęta została dopiero w Kodeksie kar głównych i poprawczych z 1847 roku. Na ziemiach polskich roty takie zostały utworzone w Zamościu i Modlinie. Pierwszą regulacją dotyczącą urządzenia rot aresztanckich (choć te w praktyce dawno już funkcjonowały) było wydane przez Radę Administracyjną postanowienie 
kiego mieli, co do zasady, pracować wewnątrz zakładu, oddzielnie od więźniów poprawczych. Wprowadzenie w życie omówionego postanowienia Rady Administracyjnej zadecydowało o potrzebie odpowiedniego dostosowania rozwiązań zawartych w instrukcji więziennej z 1823 roku. Odpowiedzią na reorganizację systemu zatrudniania skazanych było wydane 16 maja 1833 roku „Urządzenie tymczasowe porządku i karności więźniów dla więzień, w których fabryki są zaprowadzane"46. Akt ten przewidywał pięć kategorii skazanych, zwanych klasami — więźniowie śledczy; więźniowie odbywający karę aresztu publicznego; skazani za przestępstwa skarbowe; więźniowie poprawczy oraz więźniowie ciężcy, którzy skazani byli po raz pierwszy na mniej niż 10 lat więzienia ciężkiego lub skazani po raz drugi na mniej niż 5 lat; więźniowie warowni oraz skazani na więcej niż 10 lat, a w przypadku recydywy — więcej niż 5 lat więzienia ciężkiego ${ }^{47}$. Osadzeni będący w śledztwie winni być oddzieleni od pozostałych kategorii, najlepiej w specjalnie tworzonych osobnych aresztach, a w razie braku takowych - w osobnych oddziałach więzień karnych. Regulacjom zawartym w omawianym „Urządzeniu” podlegali tylko wtedy, gdy na własne życzenie i za zgodą sądu byli zatrudniani w warsztatach więziennych. Skazani na areszt publiczny powinni być także umieszczani w innych miejscach niż więzienia karne. W sytuacji niemożności realizacji tego postanowienia powinni przebywać w wydzielonych wyłącznie dla tej kategorii celach, tak aby wykluczyć możliwość stykania się z innymi kategoriami skazanych. Na życzenie aresztantów należało dostarczyć im do ich cel pracę, nie wolno jednak było ich zatrudniać w warsztatach.

z dnia 31 lipca/12 sierpnia 1834 roku. Na mocy tego postanowienia zorganizowane miały być (mimo że już istniały) kompanie aresztanckie nr 45 w Zamościu i nr 44 w Modlinie. Do kompanii (rot) odsyłani mieli być skazani na więzienie warowne, na więzienie ciężkie od 10 lat oraz recydywiści skazani na więzienie ciężkie od lat 5 . Do kompanii trafiały także osoby bez wyroku sądowego, wysyłane tam na mocy szczególnego rozkazu cara lub namiestnika. Kompanie te podlegały całkowicie władzom wojskowym, aczkolwiek fundusze na utrzymanie więźniów asygnowane były przez administrację cywilną. Więźniów dzielono na dwie klasy: więźniów ciężkich i więźniów warownych. Używano ich głównie do prac fortecznych. Starych i słabych przydzielano do prac gospodarczych i porządkowych. Używanie skazanych z tych dwóch polskich rot do robót innych niż skarbowe, w przeciwieństwie do praktyki w rosyjskich rotach, było surowo zabronione. Więźniowie byli skuci kajdanami. Za niedbalstwo i lenistwo w pracy karano na miejscu, wymierzając do 26 uderzeń trzciną podoficerską. W 1836 roku utworzono tak zwany III oddział aresztantów przy kompaniach w Zamościu i Modlinie. Przeznaczony był on dla notorycznych złodziei. Utworzenie oddziału III miało bezpośredni związek z chęcią ograniczenia zjawiska włóczęgostwa. Był to instrument wymierzony w coraz liczniejsze rzesze bezrobotnych i bezdomnych. Oddział ów miał charakter środka represyjno-zabezpieczającego. Umieszczenie w tym oddziale było wynikiem zagrożenia, jakie stwarzały te grupy społeczne. Podstawą była decyzja odpowiednich władz policyjnych wydawana w okolicznościach podejrzenia o popełnienie nowego przestępstwa, gdy podejrzany uprzednio był co najmniej dwa razy karany za kradzież. M. Senkowska, op. cit., s. 162 n; oraz E. Kaczyńska, Ludzie ukarani.., s. 350 n.

46 ZPA III 303. Akt ten w założeniu mający charakter rozwiązania przejściowego w praktyce funkcjonował aż do uchwalenia w 1847 roku nowego Kodeksu kar głównych i poprawczych.

47 M. Senkowska, op. cit., s. 136. 
Ukarani karą pozbawienia wolności za przestępstwa skarbowe mogli być zatrudniani wyłącznie w sytuacji, gdy orzeczona wobec nich kara była dłuższa niż 6 miesięcy oraz gdy - pomimo zajęcia pracą wszystkich więźniów karnych znajdowałyby się jeszcze wolne stanowiska pracy w przywięziennych warsztatach. Wszelkie rozmowy podczas pracy były zakazane. Skazanym wolno było odzywać się tylko w odpowiedzi na pytanie zwierzchników lub dozorców robót. Interesującym rozwiązaniem było wyraźne zobowiązanie majstrów kierujących warsztatami, aby w pełnieniu swoich obowiązków, zwłaszcza w zakresie nauki zawodu, wykazywali pełną gorliwość (art. 35). Praca trwała od godziny 6:00 rano w lecie, w zimie od godziny 8:00 do 12:00 oraz od godziny 14:00 do 19:00. W sobotę prace kończono w południe, a w godzinach po południowych sprzątano warsztaty ${ }^{48}$.

Polityczna sytuacja Królestwa Polskiego po upadku powstania listopadowego, w związku z rozpoczętym przez Rosję procesem likwidacji odrębności ustrojowej Królestwa, w praktyce stała się głównym hamulcem rozpoczętych w latach trzydziestych XIX wieku zasadniczych reform systemu penitencjarnego. Wprowadzenie w 1847 roku nowego Kodeksu kar głównych i poprawczych wzorowanego na rosyjskim kodeksie z 1845 roku było wyraźnym krokiem wstecz. Zmiana ta dla więziennictwa oznaczała zatrzymanie reform, a przede wszystkim znaczne pogorszenie warunków odbywania kary. W ciągu następnych lat po wprowadzeniu nowego kodeksu nastąpiło znaczne przeludnienie więzień, wzrosła śmiertelność wśród skazanych, praktycznie zrezygnowano z segregacji skazanych. Ostatnia faza unifikacji instytucji prawnych Królestwa Polskiego, rozpoczęta po powstaniu styczniowym, pogłębiła tylko kryzys w więziennictwie. Zdecydowany proces rusyfikacji oznaczał dla więziennictwa likwidację 29 lutego/12 marca 1868 roku Komisji Rządowej Spraw Wewnętrznych i przejście pod kierownictwo rosyjskiego Ministerstwa Spraw Wewnętrznych (MSW). W 1879 roku utworzono Główny Zarząd Więzienny, podległy początkowo rosyjskiemu MSW, a od końca 1895 roku Ministerstwu Sprawiedliwości.

48 Za pierwszą założoną tak zwaną fabrykę więzienną uznaje się utworzoną w 1832 roku w warszawskim ,domu kary i poprawy” fabrykę grubego płótna na sienniki, w której produkowano także ręczniki i ubiory letnie dla więźniów (fabryka zatrudniała 160 osób, a jej roczna produkcja przekraczała 27 tysięcy łokci tkanin). Kolejne to: fabryka w Sandomierzu, założona w 1834 roku produkująca sukno na zimowe ubiory więzienne (zatrudniała 60 osób); przędzalnie wełny w więzieniach w Kielcach i Janowie (zatrudniające 90 osób); fabryka kołder wełnianych w Pyzdrach wraz z pomocniczą przędzalnią wełny w Kaliszu; fabryka płótna w Lublinie z pomocniczymi przędzalniami w Łukowie i Białej. Poza tym funkcjonowały jeszcze fabryki w Płocku, Pułtusku, Łomży, Kalwarii i Łęczycy. M. Czerwiec, op. cit., s. 71; oraz K. Pawlak, op. cit., s. 30. 


\section{IMPRISONMENT IN POLAND FROM THE 15TH CENTURY TO THE MIDDLE OF THE 19TH CENTURY}

\section{Summary}

The study presents the development of imprisonment in Poland up to the 19th century. The old Polish law, in the scope of broadly understood punishments in the wild, provided for several significantly different forms of isolation. These differences were a consequence of the entities to which they could be used, the manner of execution, and the consequences of use (disgraceful or non-disgraceful). The places of its execution were also varied. These could have been dungeons, fortresses, castles, monasteries, prisons, taverns rented for this purpose, or the house of the convict. Imprisonment sanctions becoming markedly accelerated, changed the system of medieval execution of penalties based on corporal punishment in the direction of modern penal systems, based on isolation, as an independent and dominant criminal sanction.

Keywords: imprisonment, history of punishment, prison, criminal law

\section{BIBLIOGRAFIA}

Bardach J., Leśnodorski B., Pietrzak M., Historia ustroju i prawa polskiego, Warszawa 1994.

Borowski S., Ściganie przestępstw z urzędu w średniowiecznym prawie polskim, Warszawa 1933.

Czerwiec M., Więzienioznawstwo. Zarys rozwoju więziennictwa, Warszawa 1958.

Kaczmarczyk Z., Leśnodorski B., Historia państwa i prawa Polski od połowy XV w. do r. 1795, red. J. Bardach, t. 2, Warszawa 1957.

Kaczyńska E., Człowiek przed sądem. Społeczne aspekty przestępczości w Królestwie Polskim 1815-1914, Warszawa 1982.

Kaczyńska E., Ludzie ukarani. Więzienia i system kar w Królestwie Polskim 1815-1914, Warszawa 1989.

Kalisz T., Zatrudnienie skazanych odbywajacych kare pozbawienia wolności, Wrocław 2004.

Karpiński A., Pauperes, o mieszkańcach Warszawy XVI i XVII w., Warszawa 1983.

Lelental S., Wyktad prawa karnego wykonawczego z elementami polityki kryminalnej, Łódź 1996.

Maciejewski T., Rozdział 1. Rozwój prawa karnego, [w:] System prawa karnego, t. 2. Źródta prawa karnego, red. T. Bojarski, Warszawa 2011.

Maisel W., Poznańskie prawo karne do końca XVI wieku, Poznań 1963.

Maksymowicz K., Z problematyki ksztattowania się instytucji kary opartej na pracy w polskim prawie karnym, [w:] Księga pamiątkowa ku czci Profesora Józefa J. Wąsika, red. L. Bogunia, Wrocław 1999.

Migdał J., Raglewski J., Kara pozbawienia wolności. Zarys dziejów polskiej doktryny, prawa i polityki penitencjarnej, Gdańsk 2005.

Mikołajczyk M., Przestępstwo i kara w prawie miast polski południowej XVI-XVIII wieku, Katowice 1998.

Osoba A., Z dziejów polskiej dziewiętnastowiecznej myśli penitencjarnej, „Przegląd Więziennictwa Polskiego" 2001, nr 32-33.

Pawlak K., Za kratami więzień i drutami obozów. (Zarys dziejów więziennictwa w Polsce), Kalisz 1999.

Porowski M., Społeczne inicjatywy na rzecz więźniów, Warszawa 1991.

Potocki K., Uwagi do Projektu ogólnego i szczególnego ulepszenia stanu i administracji więzień publicznych w Królestwie Polskiem, [w:] Księga jubileuszowa więziennictwa polskiego 19181928, red. Z. Bugajski, Warszawa 1929. 
Rabinowicz L., Podstawy nauki o więziennictwie, Warszawa 1933.

Rafacz J., Dawne polskie prawo karne, Warszawa 1932.

Rafacz J., Więzienie marszałkowskie w latach 1767-1795, Lwów 1932.

Senkowska M., Kara więzienia w Królestwie Polskim w pierwszej połowie XIX wieku, Wrocław-Warszawa-Kraków 1961.

Sójka-Zielińska K., Historia prawa, Warszawa 1997.

Śliwowski J., Akta Rady Stanu Księstwa Warszawskiego; Więzienia i Arsztanci, Sek. II Nr 12A, $\mathrm{Nr}$ rd. 121.

Śliwowski J., Kodeks Karzący Królestwa Polskiego (1818 r.). Historia jego powstania i próba krytycznej analizy, Warszawa 1958.

Taubenschlag R., Prawo karne polskiego średniowiecza, Lwów 1934.

Walczak S., Narodziny i rozwój koncepcji wykonywania kary pozbawienia wolności, [w:] Księga jubileuszowa więziennictwa polskiego 1918-1988, red. A. Marek, Warszawa 1990.

Walczak S., Poglady J.U. Niemcewicza na prawo karne i wykonywanie kary, „Przegląd Penitencjarny" $1963, \mathrm{nr} 1$.

Wąsik J.J., Kara dożywotniego więzienia w Polsce, Warszawa 1963.

Zarzycki W., Więziennictwo w czasach Królestwa Polskiego (1818-1840), „Problemy Praworządności" 1983, nr 2. 